Artigo recebido em 28/04/2015 Aprovado em 24/09/2015

Ana Cristina Spannenberg Universidade Federal de Uberlândia anaspann@gmail.com Jornalista, professora do Curso de Jornalismo da Universidade Federal de Uberlândia, doutora em Ciências Sociais (UFBA/2009) e mestre em Comunicação e Cultura Contemporâneas (UFBA/2004)

${ }^{1}$ Uma versão preliminar do presente artigo foi apresentada no XXXV Congresso Brasileiro de Ciências da Comunicação, em setembro de 2012, em Fortaleza/CE.

\section{O leitor das páginas policiais: Notas sobre as estratégias de construção da recepção nos jornais impressos ${ }^{1}$}

\author{
Ana Cristina Spannenberg
}

\section{Resumo}

$\mathrm{Na}$ produção de um texto jornalístico há sempre um leitor previsto, que pode ser identificado por marcas textuais e gráficas deixadas na mensagem. Diversas abordagens teóricas buscam identificar tal leitor, considerando esse o primeiro passo antes de uma análise com o receptor empírico. O presente artigo apresenta os modelos propostos por Teun Van Dijk e Klaus Bruhn Jensen, a "compreensão da notícia" e os "super-temas", respectivamente. A partir deles e de outras referências, propõe um breve exercício analítico de reportagens com temática policial publicadas pelos jornais Folha de S. Paulo e O Estado de S. Paulo, buscando fazer algumas inferências sobre quem é o leitor previsto em tais publicações e quais as estratégias de construção da recepção adotadas.

\section{Palavras-chave}

Jornalismo impresso, Processo de leitura, Editoria policial.

\begin{abstract}
When producing a journalistic text there is always an expected reader, who may be identified by text and graphic marks left in the message. Several theoretical approaches try to identify such reader, considering this as the first step before an evalution with the empiric receptor. The current article presents the models proposed by Teun Van Dijk and Klaus Bruhn Jensen, the "comprehension of the news" and the "super-themes", respectively. From these and other references, it proposes a short analytical exercise over police related news published by the newspapers Folha de São Paulo and O Estado de São Paulo, trying to draw inferences about who is the expected reader on such publications and which are the adopted strategies for reception construction.
\end{abstract}

\section{Keywords}

Printed newspaper, Reading process, Police section. 
${ }^{2}$ Angela Kleimam e Dominique Maingueneau aproximam-se bastante nas suas descrições, embora utilizem definições diferentes $-a$ primeira chama de "conhecimento", e o segundo, “competência”, a esse conjunto de saberes prévios. $O$ que Kleimam (1989,

p. 16-21) chama de "conhecimento textual" está muito próximo do que Maingueneau (2001, p. 41-42) denomina

"competência genérica". Assim como o "conhecimento de mundo", também pode ser comparado à "competência enciclopédica”.

Os autores

concordam apenas na denominação da competência linguística.

${ }^{3} N a \tilde{o}$ é intenção se discutir no presente artigo as abordagens teóricas que analisam a presença do leitor no texto de modo geral. Para mais informações, ler: CHARTIER, 1996; ECO, 1986; HARTLEY, 1982; ISER, 1996, 1999; MORLEY, 1999; VERON, 1985

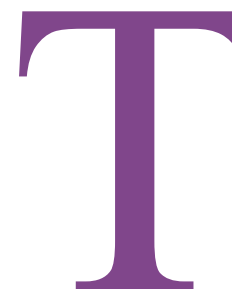

odo texto prevê um leitor que, ainda que se distancie do receptor empírico, está inserido nas entrelinhas como estratégia textual e deixa marcas que podem ser identificadas. Essas estratégias são definidas pela instância da produção e destinadas a "capturar" o receptor com o qual se pretende comunicar. Assim, é possível definir a leitura como "uma interação à distância entre leitor e autor via texto" (KLEIMAN, 1989, p. 65). Essa interação pode ser também produtora de sentidos para o texto (GOULEMOT, 1996, p. 107). Para ele, ler "não é encontrar o sentido desejado pelo autor, o que implicaria que o prazer do texto se originasse na coincidência entre o sentido desejado e o sentido percebido, em um tipo de acordo cultural como algumas vezes se pretendeu" (GOULEMOT, 1996, p. 108), mas conferir um sentido novo, construir um sentido comum entre texto e leitor.

$\mathrm{O}$ texto exige do leitor certos tipos de conhecimentos necessários para sua compreensão. São eles que poderão trazer grandes pistas sobre a qual leitor o texto pretende dirigir-se. Esses conhecimentos - ou competências, como preferem alguns autores -, podem ser linguísticos, textuais e conhecimentos do mundo. $\mathrm{O}$ primeiro tipo diz respeito ao domínio da linguagem do texto, fundamental para a sua compreensão semântica e sintática, do qual decorre o "processamento" do texto, primeiro passo para a leitura (KLEIMAN, 1989, p. 14-16). Já a competência textual está ligada à capacidade do leitor em reconhecer diferentes tipos de texto, pois "o conhecimento das estruturas textuais e de tipos de discurso determinará, em grande medida, suas expectativas em relação aos textos, expectativas estas que exercem um papel considerável na compreensão" (KLEIMAN, 1989, p. 20). Por fim, o conhecimento de mundo diz respeito a todo conjunto de saberes acumulados pelo leitor que podem ser adquiridos tanto formal quanto informalmente (KLEIMAN, 1989, p. $20)^{2}$.

É esse conhecimento prévio, em sua interação com a informação nova, que constituirá o resultado da leitura de um texto, porque é a partir dele que o leitor poderá fazer "inferências sobre o texto" (KLEIMAN, 1989, p. 25). "Há evidências experimentais que mostram com clareza que o que lembramos mais tarde, após a leitura, são as inferências que fizemos durante a leitura; não lembramos o que o texto dizia literalmente" (KLEIMAN, 1989, p. 25). Tal observação admite como fundamental a atividade do leitor, visto que é apenas pela interação entre as duas instâncias - texto e leitor - que o primeiro adquire sentido. Diversos estudiosos procuram tratar dessa relação entre o texto e seu receptor ou daquilo que Umberto Eco chama de "fantasma de leitor" (2000), ou seja, o leitor que está presente no texto, porque o conduz e determina suas escolhas, como uma estratégia ${ }^{3}$.

Contudo, é preciso destacar que a atividade do leitor não é movida apenas por intenções subjetivas, pois, sendo assim, cada texto poderia ter infinitas leituras. Existem condicionantes históricas e sociais que também exercem papel importante, estabelecendo o que Jesús Martín-Barbero chama de "leitura como mediação", ou seja, de uma atividade que procura "ir das estruturas dos textos às estruturas da sociedade ou vice-versa" (MARTÍN-BARBERO, 2001, p. 191). 
Isso ocorre mediante a incorporação do "mundo do leitor" ao texto, que pode ser vista por meio do uso de dispositivos de composição gráfica, de fragmentação da leitura, de sedução e de reconhecimento (MARTÍN-BARBERO, 2001, p. 192197).

No presente artigo, pretendemos apresentar duas propostas conceituais que buscam analisar as marcas deixadas pela instância da produção e sua relação com o processo de recepção destes textos, a "compreensão da notícia", de Teun Van Dijk, e os "super-temas", de Klaus Bruhn Jensen. Em um breve exercício analítico, apresentaremos ainda a análise de reportagens da editoria de polícia publicadas pelos jornais Folha de $S$. Paulo e $O$ Estado de S. Paulo, nas quais buscaremos fazer algumas inferências sobre suas estratégias de construção da recepção, aplicando parcialmente os modelos apresentados, no que tange à análise apenas do produto e recorrendo também a outros referenciais que possibilitam tal identificação ${ }^{4}$.

\section{Processo de leitura}

A leitura enquanto processo de aquisição de novas informações e conhecimentos tem encontrado diversas explicações em teorias de áreas como a psicologia e a educação. No campo da comunicação alguns autores debruçaramse sobre tal processo tentando explicálo. Apresentaremos a seguir as propostas de Teun Van Dijk (1990) e Klaus Bruhn Jensen (1998) para entender tal fenômeno.

$\mathrm{O}$ primeiro apresentou seu modelo de compreensão da notícia tendo como objeto empírico os jornais impressos. As contribuições para sua construção vêm da Psicologia Cognitiva e da
Inteligência Artificial e seu modelo foi testado empiricamente em uma pequena experiência realizada em Amsterdã, na Holanda. Já a segunda proposta, de Jensen, fez parte de um projeto, envolvendo sete países, que buscava verificar como os receptores de telejornais apropriam-se do conteúdo noticiado e o aplicam em sua vida cotidiana.

\section{A compreensão da notícia}

Ao propor uma teorização do processo de compreensão da notícia, Teun Van Dijk divide-o em seis etapas e explica que podemos chamar de "leitura" o processo como um todo, mas que também denomina leitura uma das suas etapas (1990, p. 203). Ana Elisa Ribeiro (2011, p. 3) explica que, para Van Dijk, "ler é uma integração entre estruturas manifestas, informação pressuposta e estratégias de interpretação".

A primeira etapa do processo de compreensão da notícia compreende a percepção e atenção. $O$ autor explica que "os processos de percepção do texto jornalístico implicam a identificação dos formatos do periódico e a distribuição do item informativo, e estão relacionados com a informação visual associada com nosso conhecimento geral dos artigos jornalísticos na imprensa" (VAN DIJK, 1990, p. 202) 5 .

A leitura é o segundo momento do processo e é entendida como "o ato voluntário específico de decodificar e interpretar um texto dado" (VAN DIJK, 1990, p. 203). Como o leitor do jornal impresso pode interromper a leitura a qualquer momento e, até mesmo, optar por não ler uma determinada matéria, Van Dijk considera que o jornal utiliza "estratégias dominantes de leitura parcial" para tentar
${ }^{4} \mathrm{O}$ presente artigo é parte da pesquisa A leitura do jornal impresso - Proposta de Construção de um modelo de análise de recepção dos jornais impressos, que está sendo desenvolvida no curso de Jornalismo da Universidade Federal de Uberlândia, sob coordenação da autora.

${ }^{5}$ Estamos utilizando uma tradução espanhola do livro de Teun Van Dijk, News as Discourse. Todas as traduções das citações foram feitas por nós, de modo livre. 
${ }^{6}$ Conforme Ana Elisa Ribeiro (2011), Van Dijk aponta três níveis de construção de uma notícia, que podem ser identificados pelo leitor: macroestrutura, superestrutura e a microestrutura. A pesquisadora explica tais categorias: " $A$ macroestrutura tem estreita relação com conteúdo e sentidos globais, enquanto a superestrutura se relaciona à forma mesma do texto, incluindo movimentos retóricos e composição. Ela não é, no entanto, o mesmo que microestrutura, que se refere a aspectos sintáticos, morfológicos e normativos do texto" (2001, pp. 3-4). prender a atenção e incentivar a leitura. Tais estratégias concentram as principais informações em elementos como título, fotos e cabeça, que logo no início do texto permitem ao leitor ter uma noção do fato principal.

O processo continua com a compreensão, que envolve todas as etapas seguintes. A terceira etapa é a de decodificação e interpretação, que ocorre principalmente através do título e da cabeça da matéria. $\mathrm{O}$ autor enfatiza o papel dessas duas categorias na compreensão do texto como um todo: "tão logo como o título tenha sido lido e interpretado, o sistema cognitivo está amplamente preparado para: 1) as decisões de continuar ou interromper a leitura, e 2) a interpretação do resto do texto" (VAN DIJK, 1990, p. 205).

Após a leitura do título de uma matéria jornalística, o sistema cognitivo do leitor deve ser capaz de identificar "a macroestruturadocontextodacomunicação (incluindo tipo de contexto, identidade do jornal, objetivos da leitura, opiniões sobre o jornal e valores jornalísticos)" (VAN DIJK, 1990); perceber o "esquema do discurso jornalístico" identificado pelo seu título; ter um fragmento semântico que permitirá identificar a sua macroestrutura ou temática, ao menos de forma provisória; levantar informações sobre modelos situacionais que envolvem tal temática (ações, personagens, circunstâncias); traçar um plano de leitura parcial, a partir do qual decidirá se continua ou não a leitura (VAN DIJK, 1990) ${ }^{6}$.

Após a interpretação do texto, as informações são armazenadas numa memória que o autor denomina "episódica", que tem a função de registrar as informações interpretadas e graválas na "memória de longo prazo" (VAN
DIJK, 1990, p. 151). Esse é o quarto passo na compreensão da notícia, a criação de uma representação do fato interpretado na memória episódica, o que vai permitir ao leitor relacionar a informação nova armazenada com as informações antigas. Essa representação, explica Van Dijk, é hierárquica, priorizando as temáticas gerais em detrimento dos detalhes (VAN DIJK, 1990, p. 208).

A etapa seguinte é a de formação, uso e atualização de modelos situacionais. "Os modelos situacionais [...] agrupam nossas experiências acumuladas sobre fatos anteriores, incluindo as interações e o discurso" (VAN DIJK, 1990, p. 153), explica o autor, e acrescenta que "para o discurso jornalístico, a compreensão frequentemente implica na recuperação e na atualização de modelos existentes" (VAN DIJK, 1990, p. 209). Portanto, são modelos ou estruturas prontas que ajudam a compreender a informação nova com base em experiências anteriores.

$\mathrm{O}$ último passo do processo de compreensão da notícia é o de usos e mudanças do conhecimento social geral e das crenças (tais como estruturas, argumentos, atitudes e ideologias). "Uma informação nova pode provocar nos leitores certas revoluções, em primeiro lugar das opiniões particulares, logo de opiniões mais gerais [...] e finalmente incluindo as atitudes gerais" (VAN DIJK, 1990, p. 210). Contudo, é preciso enfatizar, de acordo com Van Dijk, que todos os processos cognitivos de compreensão do texto não seguem regras fixas.

Um dos fatores decisivos para a retenção da informação na memória, conforme Van Dijk, é a proximidade do fato noticiado para a vida do leitor e a possibilidade dele utilizá-lo no cotidiano. $\mathrm{O}$ autor afirma isso 
quando explica que detalhes como lugares e números tendem a ser esquecidos pelos leitores, permanecendo apenas aquela informação que é fundamental para a compreensão da vida cotidiana (VAN DIJK, 1990, p. 248). Isso decorre da própria natureza do sistema cognitivo do leitor e da função dojornal no oferecimento de informação.

\section{Os super-temas}

O nível de proximidade do leitor com o tema apresentado na notícia pode, conforme a proposição de Van Dijk, ser considerado um fator decisivo na sua interpretação, visto que a memória retém mais facilmente aqueles conteúdos com os quais consegue estabelecer uma relação de conhecimento prévio. Outro fator também decisivo é a aplicação e uso desse conteúdo na vida do receptor. A análise desse uso foi proposta pelo pesquisador dinamarquês Klaus Bruhn Jensen, que coordenou uma investigação sobre telejornais em sete países diferentes (Bielo-Rússia, Dinamarca, Índia, Israel, Itália, México e Estados Unidos). A pesquisa aconteceu de 1989 a 1997, através do projeto News of the World, que realizou entrevistas e grupos de discussão em famílias buscando analisar como as pessoas entendem e interpretam as notícias com base em suas vidas cotidianas.

As análises utilizaram como categoria principal os super-temas ${ }^{7}$, que são

[...] construções temáticas através das quais os telespectadores podem estabelecer relações entre o mundo de suas vidas cotidianas e o mundo tal como representado nos relatos das notícias televisivas. Super-temas podem ser vistos como mediadores entre os espectadores e o relato por traduzir uma realidade que aparece complexa e distante em termos simples, gerais e pessoalmente compreensíveis (JENSEN, 1998, p. 19) ${ }^{8}$.

Essa categoria foi pensada e desenvolvida devido a pesquisas anteriores sobre a recepção de telejornais cujos resultados demonstravam que, às vezes, a história contada pelos espectadores após a assistência do programa diferia bastante daquela contada pelos jornalistas em determinada notícia.

Conforme Mancini, Pimpinelli e Di Michele, responsáveis pela pesquisa do projeto News of the world na Itália, a interpretação do conteúdo acontece em diversos níveis e com diferentes procedimentos de decodificação. "Os espectadores incorporam informações no descanso de suas atividades diárias e apropriam-se da realidade que os cerca dando significadopara aquilo que eles veem e escutam" (MANCINI; PIMPINELLI; DI MICHELE, 1998, p. 105)9. Esse processo, conforme os autores, ocorre em quatro níveis: o evento, a história, o eu e o meio. Tais níveis compõem diferentes momentos do processo de construção dos super-temas e podem ser vistos tanto como "sequenciais e verticais" quanto como uma "progressão circular e contínua" (MANCINI; PIMPINELLI; DI MICHELE, 1998, p. 106).

$\mathrm{O}$ primeiro nível de atuação dos super-temas é o "evento em si", no qual "fragmentos particulares da história são simplesmente ressaltados antes de serem inseridos numa estrutura mais completa de significados"10 (MANCINI;
${ }^{7} \mathrm{O}$ conceito de supertema foi apresentado pela primeira vez por Jensen no artigo News as social resource: a qualitative empirical study of the reception on danish television news, publicado no European Journal of Communications, vol. 3, n. 3, 1988, pp. 275301 .

${ }^{8}$ No original: "thematic constructs by which viewers may establish links between the world of their everyday lives and the world as represented in television news stories. Super-themes can be seen to mediate between viewer and story by translating a reality that appears complex and distant into simple, general, and personally meaningful terms", (Tradução nossa).

${ }^{9}$ No original:

"Viewers incorporate information into the rest of their daily activities and appropriate the surrounding reality by giving significance to what they see and hear" (Tradução nossa). 
${ }^{10}$ No original: “[...] fragments of a story are simply highlighted before they are inserted into a more complete framework of meaning"

(Tradução nossa).

${ }^{11}$ No original: "From this overall informative

context - the context

which becomes text through interpretation - the viewers is able to accomplish a first stage

of contextualization, giving a certain

finality to the events represented" (Tradução nossa).

${ }^{12}$ No original: "The 'self', accordingly, has been introduced as an entity comprising many componentes such as personal life, everiday experiences, professional activity, general

knowledge, emotios, etc." (Tradução nossa).

${ }^{13}$ No original: "Having gathered informations

from several sources, the self will ascribe relevance and informative value to those events it most readily remembers"

(Tradução nossa).

${ }^{14}$ No original: "the urgency of speaking about facts that are particularly dear and close to an individual's own reality causes a distancing of the self from news items along entirely individual, independent tracks, even to the point of misremembering them, so that nothing substantial remains of the original piece of news the engendred the family discussion. Personal life may thus prevail over the public news item as viewers refer an entire story to the personal dimension of their individual past, needs, and interests, or

to their family acting as an interpretive community" (Tradução nossa).

PIMPINELLI; DI MICHELE, 1998, p. segundo plano. Eles afirmam que

106). Nesse primeiro momento, apenas são destacados alguns itens da notícia, como o nome de pessoas e lugares, mas esses apenas poderão ser interpretados quando inseridos em uma estrutura mais complexa de linguagem, através de uma narrativa.

A "história" é o segundo nível dos super-temas, na qual o receptor utiliza informações complementares, como outros meios de comunicação e sua própria experiência pessoal para iniciar a interpretação do evento. "Partindo desse contexto informativo global - o contexto no qual se transformam os textos através da interpretação - o espectador está habilitado a realizar um primeiro estágio de contextualização, oferecendo uma certa finalidade para os eventos representados"11 (MANCINI; PIMPINELLI; DI MICHELE, 1998, p. 106).

A etapa seguinte no processo é dada pelo "eu” do espectador. "O 'eu', portanto, tem sido introduzido como uma entidade formada por muitos componentes, tais como a vida pessoal, as experiências do dia a dia a atividade profissional, conhecimentos gerais, emoções etc."12 (MANCINI; PIMPINELLI; DI MICHELE, 1998, pp. 106-107). Essa fase é marcada pela seleção, decodificação e memorização seletiva dos eventos. "Tendo reunido informações de várias fontes, o eu atribuirá relevância e valor informativo para aqueles eventos que mais facilmente são lembrados"13 (MANCINI; PIMPINELLI; DI MICHELE, 1998, p. 107).

Os autores ressaltam dentro desse processo que as informações trazidas pelo "eu", muitas vezes, acabam predominando sobre a notícia em si, que é deixada em um
[...] a urgência de falar sobre os fatos que são particularmente queridos e próximos para o próprio indivíduo causa a distância desse indivíduo dos novos itens ao longo de sua vida, linhas independentes, até mesmo os pontos de perda de lembrança delas, até que nada substancial permaneça do pedaço original das notícias que iniciaram a discussão familiar. A vida pessoal, dessa forma, pode prevalecer sobre os itens de notícias públicas quando os espectadores referem uma história inteira para a dimensão pessoal de seus passados individuais, necessidades e interesses, ou para a ação familiar como uma interpretação comunitária $^{14} \quad$ (MANCINI; PIMPINELLI; DI MICHELE, 1998, p. 107).

A última etapa do processo diz respeito a uma história de uso do "meio de comunicação" pelo receptor. Segundo os autores, ela envolve tanto o hábito de recepção de determinado meio quanto sua relação com os outros e permite, portanto, interagir, interpretar e julgar a notícia, comparando o tratamento que ela recebe em diferentes meios e diferentes suportes. Tais informações são dadas através das

[...] competências que os espectadores têm desenvolvido previamente, primeiramente através da experiência dos próprios meios de comunicação de massa, mas também através de 
experiências pessoais, permitindo que eles interajam com a mídia, interpretando e julgando tanto a qualidade da informação quanto o ponto de vista da televisão em oposição aos pontos de vista trazidos por outros meios ${ }^{15}$ (MANCINI; PIMPINELLI; DI MICHELE, 1998, p. 107).

Os super-temas são construídos a partir e através desse processo que passa pelos quatro diferentes níveis de interpretação da notícia. Mancini, Pimpinelli e Di Michele definem assim os super-temas e seu processo de construção: "Enquanto o evento, a história, o eu e a crítica dos meios todos constituem possíveis níveis de interpretação, o super-tema é, por assim dizer, o produto final extraído de uma certa sensação, intermediária entre a exposição do espectador ao meio e sua vida diária"16 (1998, p. 107).

Como defendido em oportunidade anterior $^{17}$, consideramos interessante a utilização dos super-temas, em um primeiro momento, para análise do próprio produto jornalístico para que tais resultados possam, numa etapa posterior, ser confrontados com os relatos dos receptores e forneçam uma visão ampla do modo como se dá a recepção do produto jornal impresso. Consideramos, assim, que o modelo de Jensen pode ser produtivo para tal análise, ainda que careça de ajustes, visto ter sido proposto para o meio televisivo.

\section{A reportagem de temática policial}

Ao analisar textos jornalísticos, Van Dijk (1990), como já dito, considera o tema importante porque prevê um saber do leitor e deixa lacunas para serem preenchidas, conduzindo e interferindo na interpretação.

Segundo o autor, a interpretação de um determinado texto jornalístico inicia antes da leitura completa deste, começa quando o leitor faz conjecturas a respeito do tema (VAN DIJK, 1990, p. 59). Assim, pode-se afirmar que o tema é um dos fatores que prepara a recepção. O autor explica que "o tema atua como uma instância de controle principal sobre a posterior interpretação do resto do texto. Quando conhecemos o tema, é mais fácil compreender as respectivas orações do texto" (VAN DIJK, 1990, p. 59).

Partindo dessa ideia, pode-se considerar que o texto jornalístico é organizado de forma temática apostando que o leitor possua um saber prévio necessário para preencher as lacunas deixadas no texto. Por esse motivo, optamos por selecionar reportagens da editoria de polícia para um breve exercício de análise da presença do leitor proposto, aplicando os conceitos propostos e recorrendo a outros referenciais que permitem uma visão mais ampliada. As sete reportagens a serem apresentadas foram selecionadas em um corpus de 20 edições dos jornais Folha de S. Paulo, O Estado de S. Paulo e O Globo, entre os meses de junho a dezembro de 2002, nas quais foram selecionadas 28 reportagens e 31 artigos opinativos ${ }^{18}$. É importante destacar que a análise proposta no presente artigo está focada apenas no produto jornalístico em si, portanto, permite somente a aplicação parcial dos modelos propostos alhures, que são voltados à recepção empírica ${ }^{19}$.

As reportagens da editoria de polícia utilizam diversos recursos com uma intenção aparente, a de dramatizar a notícia. O primeiro elemento que compõe essa estratégia são os títulos, sempre
${ }^{16}$ No original: "Whereas the event, the story, the self, and media criticism all constitute possible levels of interpretation, the super-theme is, so to speak, the final product of extracting a certain sense which is an intermediary between the viewers' exposure to the medium and their everyday life"

(Tradução nossa).

${ }^{17}$ Uma proposta para sua aplicação na análise das estratégias de construção do receptor pelos telejornais

baianos pode ser encontrada em GOMES; SPANNENBERG, 2003.

${ }^{18}$ Tal recorte compõe a dissertação A construção do leitor no jornal impresso - Estratégias de construção da recepção

dos gêneros artigo opinativo e reportagem nos jornais Folha de São Paulo, O Estado de São Paulo e O Globo, desenvolvida no Programa de Pós-Gradução em Comunicação e Cultura Contemporâneas (Facom/ UFBA), sob orientação da prof. Dr ${ }^{a}$ Itania Maria Mota Gomes e defendida em maio de 2004. A intenção dessa pesquisa foi identificar estratégias de construção da relação texto/leitor, usando como pressuposto teórico a ideia de que todo texto prevê sua recepção, construindo em si a imagem do seu leitor presumido, apresentada por diversas correntes teóricas, decorrentes de diferentes perspectivas (cf. CHARTIER, 1996; ECO, 1986; HARTLEY, 1982; ISER, 1996, 1999; MORLEY, 1999; VERON,

1985), e relacionar tais estratégias com as coerções de cada gênero jornalístico.

\section{${ }^{19}$ Ressalte-se que} consideramos esta a primeira etapa analítica a ser desenvolvida na pesquisa de recepção, visto que só após sua conclusão será possivel executar a análise com receptores, como previsto na pesquisa A leitura do jornal impresso [...], supracitada. 
${ }^{20}$ Estamos utilizando a classificação de fotografias jornalísticas propostas pelo pesquisador argentino Eliséo Verón, que divide as imagens em quatro categorias, considerando que elas, inseridas em um meio de comunicação, acabam subordinadas a "contextos discursivos" que regulam e determinam o funcionamento da imagem (2003, p.

12). Foto testemunhal é o tipo "clássico" de foto jornalística, pois está ligada diretamente à atividade do repórter, com sua presença no cenário dos acontecimentos (2003, p. 13). A foto pose, conforme Verón, "é um presente do personagem fotografado ao fotógrafo (e por seu intermédio ao leitor)"

(2003, p. 14). Nela, geralmente pessoas que já possuem um status na mídia aparecem sorrindo e olhando para a câmara (2003, p. 16). Já a foto retórica das paixões diz respeito a flagrantes de expressões faciais de pessoas públicas em situações as mais diversas, que traduziriam seu "estado de espírito" (2003, p. 15-16). Por fim, a foto categorial ocorre quando uma imagem singular é utilizada para caracterizar uma classe.

O autor cita exemplos como a foto de uma mulher sozinha em uma mesa de restaurante, em uma matéria cujo título é "MULHERES: a geração sem marido" (2003, p. 17) fortes e com apelo dramático, como nos seguintes exemplos: "Tiros no trânsito. E adeus Tainá, 5 anos" (OESP, 13 de agosto de 2002), "Capão Redondo, numa só noite, cinco mortos" (OESP, 8 de julho de 2002), "Juiz é condenado por homicídio da mulher" (FSP, 14 de dezembro de 2002). Sem deixar de cumprir sua função de mostrar ao leitor qual é o assunto da matéria e "despertar seu interesse" para a leitura (SILVA, 1985, p. 143), o título da reportagem policial dá o tom do texto, carregado de dramaticidade.

Em quatro das sete reportagens policiais analisadas, a foto que acompanha a matéria tem função meramente ilustrativa, ou seja, não traz a informação no momento que ela ocorre, como seria na foto "testemunhal" $(\text { VERON, 2003, p. 13) })^{20}$. Tal opção pode ser explicada como uma tentativa de não chocar o leitor com cenas violentas (tal como fazem os jornais classificados como "sensacionalistas"), mas de capturá-lo pela emoção. É o que ocorre, por exemplo, na reportagem já mencionada sobre a menina Tainá (OESP, 13 de agosto de 2002), de cinco anos, morta em uma briga de trânsito. A foto escolhida como principal, ocupando lugar central e aberta em três das seis colunas que compõem a página, mostra a menina em plano fechado, sorrindo.

Em apenas duas das reportagens as fotos apresentam caráter testemunhal ("Time de presos perde o último jogo da detenção" OESP, 11 de setembro de 2002 e "Medo fecha comércio na região central de SP" - FSP, 8 de novembro de 2002), porém, sem conter o mesmo peso dramático das outras, já que não apresentam cenas de grande violência. Uma das reportagens policiais não traz fotografia alguma ("Juiz é condenado por homicídio da mulher" -
FSP, 14 de dezembro de 2002), apenas um infográfico.

A opção para substituir a fotografia parece ter sido encontrada nos infográficos, que acompanham cinco das reportagens policiais. Os gráficos facilitam a leitura e permitem reproduzir cenas ou locais que não seriam possíveis através da fotografia. É o que ocorre na matéria "Tráfico em SP imita o Rio e sitia favela" (FSP, 9 de junho de 2002), na qual, através de gráfico, desenha-se o mapa das favelas cariocas, indicando sua localização e os acontecimentos que as marcaram. De forma ainda mais clara, esse recurso aparece na já mencionada "Tiros no trânsito. E adeus Tainá, 5 anos". Com o infográfico, todo o crime é reconstituído por desenhos e pode ser acompanhado em uma sequência, como de histórias em quadrinhos. Esse é um recurso bastante utilizado nas reconstituições policiais feitas por telejornalismo, o storyboard, e do qual o jornal impresso se vale para conseguir informar rapidamente, resgatar uma característica de agilidade e movimento própria dos meios eletrônicos e recontar a história sem utilizar imagens violentas feitas em fotografia.

A outra característica que distingue a reportagem policial é a utilização clara de dois tipos de vozes além do narrador: a vítima e a autoridade. $\mathrm{O}$ primeiro tipo aparece geralmente em discurso direto (DD), o que pode ser explicado pela "impressão de autenticidade" que esse tipo de discurso causa (MAINGUENEAU, 2001, p. 142). A inserção da voz dos personagens na reportagem é também o único espaço reservado para a utilização do verbo em primeira pessoa na amostra analisada. A opção por orientar parte do texto para o emissor (função emotiva) 
parece querer deixar a sua fala transparente (CHALHUB, 1999, pp. 16-18) ou ao menos passar ao receptor tal impressão.

Os seguintes trechos das reportagens policiais ilustram bem essa estratégia.

Quando a casa deles foi invadida, os traficantes queriam saber se o irmão dela, de 19 anos, era da facção rival. Apesar da resposta negativa, estavam decidindo, na rua, se iam ou não matar o rapaz. 'Enquanto eles resolviam, meu irmão fugiu. Na outra noite, eles voltaram e disseram para todo mundo ouvir que, se a gente voltasse para lá, eles iam nos matar', conta a jovem" (“Tráfico em SP imita o Rio e sitia favelas" - FSP, 9 de junho de 2002).

Na garupa de uma motocicleta, Douglas Gomes, de 19 anos, desempregado, observa o lugar com ar desolado. 'Um dos mortos era meu primo. Estava dormindo quando bateram na porta para avisar que o Ivan tinha morrido. Aqui é assim mesmo, acontece tudo de ruim.' (“Capão Redondo: numa só noite, 5 mortos"-OESP, 8 de julho de 2002).

Segundo Aristóteles, na Arte Poética, "a tragédia é a imitação de uma ação importante [...] suscitando a compaixão e o terror, tem por efeito obter a purgação dessas emoções" (ARISTÓTELES, cap. VI, 2). Wilson Gomes explica que "o temor (...) é uma emoção que se origina quando vemos nosso semelhante em desdita e a compaixão, quando contemplamos alguém que é infeliz sem o merecer" (GOMES,
1996, p. 116). Ao fazer tais opções de utilização das vozes de outros, o autor acaba reforçando a carga dramática do texto e criando no receptor um sentimento de identificação e até de compaixão com as vítimas.

A voz da autoridade, que tanto pode ser da polícia como de outros representantes públicos com autoridade conferida oficialmente, aparece para explicar a versão oficial dos fatos e, principalmente, para recompor a ordem para um leitor que percebe como estranho todo o universo e os personagens retratados. Tal afirmação pode ser comprovada pela própria necessidade da presença policial, demarcada nos textos pela utilização do DD, que deve transmitir tranquilidade, o que não seria necessário para os personagens retratados, que enfatizam a violência como algo já normal em seus cotidianos.

Tal utilização fica clara na reportagem "Medo fecha comércio na região central de SP" (FSP, 8 de novembro de 2002) em que, além do chefe do setor de comunicação da Polícia Militar de São Paulo, tenentecoronel Eliseu Leite de Moraes, desmentir a notícia, oferecendo a versão oficial dos fatos, o próprio governador do Estado, Geraldo Alckmin, é convocado para tentar “acalmar" a população. A citação da fala de Moraes é a seguinte:

[...] a corporação não confirmou que um homem tivesse avisado aos proprietários de estabelecimentos comerciais do bairro, durante a madrugada, para não abrir. 'E se isso tivesse acontecido, a comunidade não deveria obedecer, mas sim acionar a polícia e passar as características do criminoso', diz 
o coronel (FSP, 8 de novembro de 2002).

Após a negação do fato, o governador entra em cena para tranquilizar o leitor: "Mesmo não conhecendo especificamente o que ocorreu, podem ter certeza de que a polícia irá para cima dos bandidos. Em São Paulo não existe toque de recolher" (FSP, 8 de novembro de 2002) e, mais adiante,

Dentro de pouco tempo o número de policiais do Estado de São Paulo será maior que o total de homens do Exército brasileiro. É uma guerra, e precisamos vencer as batalhas a cada dia. Não vamos retroceder um milímetro em nossa política de combate à criminalidade $(F S P, 8$ de novembro de 2002).

Quando comparamos a função da voz da autoridade assumida nessa reportagem com outra reportagem analisada, "Juiz é condenado por homicídio da mulher" (FSP, 14 de dezembro de 2002), é possível perceber bem o universo do leitor previsto pelo jornal. No segundo caso, o crime envolve personagens de classe social alta e parece não representar uma ameaça ao leitor, não exigindo, portanto, que uma autoridade seja chamada para tranquilizálo. Nem mesmo os mecanismos de dramatização são utilizados, o que pode demonstrar que, ao se modificar o local e os personagens apresentados na narrativa, modificam-se também os artifícios de identificação necessários para atrair o leitor.

Essa constatação também deve ser analisada a partir das noções espaciais de "aqui" e "lá" que demarcam uma distância (mental, social e geográfica) entre o evento e seu receptor (JENSEN, 1998, p. 165). Podemos pressupor que o leitor previsto pelo jornal nesse acontecimento é o público paulistano de classe média alta, que percebe com estranhamento e medo as manifestações de violência ocorridas em regiões periféricas de São Paulo, porque, embora elas sejam geograficamente próximas, elas se apresentam mentalmente distantes.

Todas essas constatações a respeito das reportagens da editoria de polícia podem ser explicadas, ainda, através da proposta de Van Dijk sobre a persuasão, apontada como uma das estratégias utilizadas pelos jornais para facilitar a retenção do conteúdo pelo leitor (VAN DIJK, 1990, p. 123-131). $\mathrm{O}$ autor cita três principais estratégias para esse processo: 1) "sublinhar a natureza factual dos acontecimentos" (por meio de descrições, testemunhos, fontes oficiais, informações precisas e citações diretas); 2) "construir uma estrutura relacional sólida para os fatos" (apresentando causas e consequências, comparando com fatos semelhantes que sejam conhecidos, utilizando argumentos conhecidos, estruturando o texto em linguagem narrativa); 3) "proporcionar informações que também possuem as dimensões de ação e emoção" (fatos que provoquem emoções fortes e opiniões diferentes a respeito desses fatos) (VAN DIJK, 1990, p. 127).

Essas estratégias, explica Van Dijk, reforçam uma característica que o autor considera presente em grande parte da população ocidental.

A atenção pelo negativo, o sensacionalismo, o sexo e a violência, inclusive em 
periódicos de qualidade (ainda que aqui mais sutilmente), satisfaz a retórica das emoções, que também conhecemos a partir dos informes de acidentes, catástrofes, desastres e crimes (VAN DIJK, 1990, p. 127).

O autor afirma também que essas estratégias são reforçadas pelo nível de proximidade entre o leitor e o fato, bem como pelas características inesperadas e anormais que ele possa ter.

A partir do exposto, podemos afirmar que as estratégias de construção da recepção nos textos da editoria de polícia funcionam como programas de efeitos, nos quais podemos detectar uma intenção e alguns recursos utilizados para atingi-la. Nos exemplos analisados foram três as estratégias enfatizadas: a dramatização da notícia, a humanização do relato e a didatização da informação. A dramatização da notícia procura despertar no leitor a identificação e a compaixão pelos personagens apresentados no relato. Isso é feito através de recursos como títulos e fotos que produzem a comoção, além da inserção de outras vozes através de discurso direto. A humanização do relato é uma estratégia que confere uma visão particularizada sobre o fato, pela ótica de um dos seus personagens. Os recursos utilizados para tanto são as fotografias e títulos não informativos, a inserção de falas em discurso direto e a inclinação à função emotiva. Outra estratégia também utilizada nas reportagens é a didatização da informação, que busca facilitar e dinamizar a leitura e ocorre, principalmente, através de infográficos e de elementos em destaque, como olhos, linha de apoio e fotos-legenda. A partir de tais estratégias, o leitor é convidado a estabelecer uma relação com o texto e a assumir uma determinada posição.

Esperamos, com esse breve exercício analítico, ter demonstrado a aplicabilidade dos modelos de Van Dijk e Jensen para observação da presença do leitor no texto. É importante lembrar, contudo, que neste momento nossa preocupação não está voltada para o leitor empírico, mas para o conjunto de saberes necessários para a compreensão do texto tal como proposto pela instância da produção. Ao analisar um produto mediático como um todo, buscando nele os traços de seu receptor ideal, devem ser levados em consideração aqueles elementos visíveis que encontram certa recorrência e permanecem estáveis em edições sucessivas, e pela recorrência das mesmas características em diferentes suportes, no nosso caso, os três jornais analisados. As nossas descobertas, ainda que iniciais, confirmam essa posição e permitem-nos falar em estratégias de construção da recepção em textos jornalísticos, tanto se os analisarmos por gêneros (reportagem) ou por temáticas (policial).

Temos consciência de que tais marcas não nos permitem compreender $\mathrm{o}$ processo de leitura do impresso como um todo, uma vez que estão limitadas a apenas um elemento - a materialidade do jornal - e não buscam identificar intenções da instância da produção e, tampouco, usos da instância da recepção. As interpretações levantadas são inferências a partir da ideia dessas duas instâncias perceptíveis no produto. Acreditamos que uma visão mais ampla do processo seria possível observando, além das estruturas formais do texto e suas temáticas, também quais os hábitos de leitura daquele leitor pretendido pela mídia ${ }^{21}$. 
Os resultados aqui obtidos não nos informam se e por que o leitor decidirá ler a reportagem, mas nos oferecem apenas uma breve ideia de seu comportamento, formação como receptor mediático e sensibilidade estética. Sabemos que construção do processo de leitura.

\section{Referências bibliográficas}

ARISTÓTELES. Arte Retórica e Arte Poética. 14. ed. Trad. Antônio Pinto de Carvalho. Rio de Janeiro: Ediouro, s/d.

CHALHUB, Samira. Funções da linguagem. 10. ed. São Paulo: Ática, 1999. Série Princípios.

CHARTIER, Roger. Práticas de leitura. Trad. Cristiane Nascimento. São Paulo: Estação Liberdade, 1996.

ECO, Umberto. Lector in fabula: A cooperação interpretativa nos textos narrativos. Trad. Attílio Cancian. São Paulo: Perspectiva, 1986. Coleção Estudos.

. Os limites da interpretação. Trad. Pérola de Carvalho. São Paulo: Perspectiva, 2000. Coleção Estudos.

GOMES, Itania Maria Mota; SPANNENBERG, Ana C.M. The world in the head: aplicação do modelo de Klaus Bruhn Jensen ao discurso dos media baianos. In: Revista Animus. Santa Maria, v.II, n. 1, 2003.

GOMES, Wilson Silva. Estratégias de produção do encanto. In: Textos de Comunicação e Cultura. Salvador, número 35, 1996.

GOULEMOT, Jean Marie. Da leitura como produção de sentidos. In: CHARTIER, Roger. Práticas de leitura. Trad. Cristiane Nascimento. São Paulo: Estação Liberdade, 1996.

HARTLEY, John. Understanding news. Londres: Routledge, 1982.

ISER, Wolfgang. O ato da leitura - Uma teoria do efeito estético, vol.1. Trad. Johannes Kretschmer. São Paulo: Ed. 34, 1996.

. O ato da leitura - Uma teoria do efeito estético, vol.2. Trad. Johannes Kretschmer. 
JENSEN, Klaus Bruhn. News of the world: World cultures look at television news. Londres: Routledge, 1998.

KLEIMAN, Ângela. Texto e leitor - Aspectos Cognitivos da Leitura. Campinas: Pontes, 1989. Coleção Linguagem/ Ensino.

LIMA, Bruno. Juiz é condenado por homicídio da mulher, Folha de São Paulo, São Paulo, 14 dez. 2002, Caderno Folha Cotidiano, p.1.

LOMBARDI, Renato. Time de presos perde o último jogo da detenção, O Estado de São Paulo, São Paulo, 11 set. 2002, Caderno Cidades, p.6.

MAINGUENAEAU, Dominique. Análise de textos de Comunicação. Trad. Cecília P. de Souza-e-Silva e Décio Rocha. São Paulo: Cortez, 2001.

MANCINI, P. PIMPINELLI, E.A. e DI MICHELE, S. Italy. In JENSEN, Klaus Bhrun. News of the world: World cultures look at television news. Londres : Routledge, 1998, 103-125.

MARTÍN-BARBERO, Jesús. Dos meios às mediações: comunicação, cultura e hegemonia. Rio de Janeiro: Editora UFRJ, 2001.

MEDO fecha comércio na região central de SP, Folha de São Paulo, São Paulo, 8 nov. 2002, Caderno Folha Cotidiano, p.1.

MORLEY, David. The Nationwide Audience: structure and decoding. In: MORLEY, David \& BRUNSDON, Charlott. The Nationwide Television Studies. London: Routledge, 1999.

PITTA, Iuri; DIAMANTE, Fábio. Tiros no trânsito. E adeus Tainá, 5 anos, O Estado de São Paulo, São Paulo, 13 ago. 2002, Caderno Cidades, p.1.

RIBEIRO, Ana Elisa. Leitor passivo? - Leitura de Jornal Impresso e atividade de sumarização. In: XX Encontro da Compós. Universidade Federal do Rio Grande do Sul, Porto Alegre, 14 a 17 jun 2011.

SOUSA, Marcos de Moura e. Capão Redondo, numa só noite, cinco mortos, O Estado de São Paulo, São Paulo, 08 jul. 2002, Caderno Cidades, p.1.

SILVA, Rafael Sousa. Diagramação: o planejamento visual gráfico na comunicação impressa. São Paulo: Summus, 1985. Coleção Novas Buscas em Comunicação.

SPANNENBERG, Ana Cristina M. A construção do leitor no jornal impresso Estratégias de construção da recepção dos gêneros artigo opinativo e reportagem nos jornais Folha de São Paulo, O Estado de São Paulo e O Globo. 2004. Dissertação (Mestrado em Comunicação e Cultura Contemporâneas) - Faculdade de Comunicação / Universidade Federal da Bahia, Salvador. 
. A leitura do jornal: notas sobre a construção de estratégias de recepção dos impressos. In: $10^{\circ}$ Encontro Nacional de Pesquisadores em Jornalismo, 2012, Curitiba. Anais eletrônicos. Curitiba: PUCPR, 2012. Disponível em: $<$ http://sbpjor. kamotini.kinghost.net/sbpjor/admjor/arquivos/10encontro/ana_cristina spannenberg. pdf $>$ Acesso em 28 set. 2015.

TRÁFICO em SP imita o Rio e sitia favela, Folha de São Paulo, São Paulo, 9 jun. 2002, Caderno Folha Cotidiano, p.1.

VAN DIJK, Teun. A. La noticia como discurso: comprensión, estructura y producción de la información. Barcelona: Paidós, 1990.

VERON, Eliséo. L'analyse du 'contrat de lecture': une nouvelle methode pour les etudes de positionnement des support presse. In: VERON, Eliseo. Les médias, expériences, recherches actuelles, applications, Paris, IREP, 1985, p. 203-229 .

. Espacios publicos en imágenes. Trad. Julián Gorodischer. Disponível em: $<$ http:// www.biblioteca.org.ar/autort.asp?texto $=$ e\&tipo=5>. Acesso em 8 mar. 2003.

Estudos em Jornalismo e Mídia está sob a licença Creative Commons 2.5 